\title{
In Vitro Anti-Acetylcholinesterase Activity of Dichloromethane Leaf Extracts of Carphalea glaucescens in Chilo partellus Larvae Njoroge W Anne $^{1 *}$, Ngugi M Piero', Aliyu Umar ${ }^{1,2}$ Matheri Felix $^{1}$, Gitahi S Maina', Mwangi B Maina', Njagi J Muriithi', Mworia J Kiambi ${ }^{1}$ and Ngure G Mutero
}

${ }^{1}$ Department of Biochemistry and Biotechnology, Kenyatta University, Nigeria

${ }^{2}$ Department of Biological Sciences, Bauchi State University Gadau, Nigeria

\begin{abstract}
Acetlycholinesterase (AChE) hydrolyses the neurotransmitter acetylcholine resulting in the termination of nerve impulse at the synapse. Anti-acetylcholinesterase activities stop the passage of the nerve impulse at the synapse resulting in continuous stimulation which can lead to death. The manufacturers of many pesticides target the AChE because it interferes with the passage of the nerve impulse. In vitro study revealed that DCM leaf extract of Carphalea glaucescens has anti-acetylcholinesterase activity against crude acetlycholinesterase (AChE) enzyme extracted from Chilo partellus and an $\mathrm{IC}_{50}$ of $12.02 \mathrm{mg} / \mathrm{ml}$ was calculated. After qualitative phytochemical screening was carried out the phytochemicals which were present were tannins, phenols, flavonoids, steroids, terpenoids and alkaloids.
\end{abstract}

Keywords: Chilo partellu; Carphalea glaucescens; Anti-acetylcholinesterase

Abbreviations: AChE: Acetlycholinesterase ; ANOVA: Analysis of Variance; DCM: Dicholomethane; WHO: World Health Organization; ACTI : Acetylthiocholine Iodide; DTNB: 5,5'-Dithiobis(2-Nitrobenzoic Acid)

\section{Introduction}

Acetylcholinesterase is the target for insecticides belonging to organophosphorus and carbamate group. Organophosphates act upon the nervous system of the pests interfering with the passage of impulse. Due to the negative effects of synthetic insecticides, there is need to develop cheaper and safer insecticides.

The Chilo partellus (spotted stem borer) is one of the major constraints in maize and sorghum production worldwide. The yield losses reported due to stem borers vary greatly. Melaku [1] reported $49 \%$ grain yield losses due to stem borers in northern Ethiopia but on average yield losses can be estimated between $20 \%$ and $50 \%$. C. partellus is very invasive and once it invades an area it displaces native species and is widely distributed. In coastal Kenya, there is evidence that $C$. partellus has partially displaced the indigenous stem borer, Chilo orichalcociliellus [2-4].

The distribution of $C$. partellus now includes Ethiopia, Kenya, Tanzania, Mozambique, Swaziland, Lesotho, and Bostwana [5,6]. Different conventional insecticides have been used to control stem borer resulting in high productivity but there are shortcomings in their application, including the high residue levels of pesticides in agricultural produce, pest resistance as well as environmental pollution [7]. The management of C. partellus has been typically carried out by synthetic insecticides, which are non-biodegradable and not environmentally safe $[8,9]$.

In this perspective, plants are considered the alternative sources of insect-control because they contain a range of bioactive compounds and many of which are selective. In Africa and elsewhere, plants extracts are still widely used in the treatment of many ailments and up to $80 \%$ of the African population use traditional medicines for health care [10]. The present study aimed to investigate the mode of action of C. glaucescens in the inhibition of acetylcholinesterase.

\section{Materials and Methods}

\section{Collection and preparation of the plant materials}

Fresh leaves of C. glaucescens were harvested from Siakago division, Mbeere North Sub County, in Embu County guided by ethnobotanical information from local farmers and herbalists. An acknowledged taxonomist authenticated the identity of the plant under study. They leaves were dried at room temperature $\left(25^{\circ} \mathrm{C}\right)$ and they were ground to powder using an electric mill. The ground sample was labeled and stored at room temperature ready for extraction.

\section{Extraction procedure}

A sample of $500 \mathrm{~g}$ of powdered plant leaves was soaked in 1 litre of dichloromethane for 24 hours. The mixture $\mathrm{w}$ a s then filtered under pressure using a vacuum pump. The filtrate was concentrated using a rotary evaporator at $40^{\circ} \mathrm{C}$ to obtain dry extract which was stored at $4^{\circ} \mathrm{C}$

\section{Crude acetlycholinesterase enzyme extraction procedure}

Crude acetlycholinesterase (AChE) enzyme was extracted from C. partellus obtained from Kenya Agricultural and Livestock Research Organization (KARLO), Katumani Station, Kenya. Third and fourth instar larvae were used for this study. After washing the larvae three times with distilled water, they were homogenized for 3 minutes $(0.5$ g) in $6 \mathrm{ml}$ sodium phosphate buffer $(\mathrm{pH} 8,0.1 \mathrm{M}$, containing $1.0 \mathrm{M}$ $\mathrm{Na}_{2} \mathrm{HPO}_{4}$ and $1.2 \mathrm{M} \mathrm{NaH}_{2} \mathrm{PO}_{4}$ ). After filtration through Whatman filter paper No. 1, the homogenate was centrifuged at 2,000 g for 20 min at $4^{\circ} \mathrm{C}$. The supernatant was used as a crude enzyme extract.

*Corresponding author: Anne W. Njoroge, Department of Biochemistry and Biotechnology, Kenyatta University, P.O. Box 43844-00100, Nairobi, Tel: +254722613829; E-mail: annwanjoroge@gmail.com

Received: February 18, 2016; Accepted: April 01, 2016; Published April 04, 2016

Citation: Anne NW, Piero NM, Umar A, Felix M, Maina GS, et al. (2016) In Vitro Anti-Acetylcholinesterase Activity of Dichloromethane Leaf Extracts of Carphalea glaucescens in Chilo partellus Larvae. Biochem Anal Biochem 5: 264 doi:10.4172/2161-1009.1000264

Copyright: $\odot 2016$ Anne AW, et al. This is an open-access article distributed under the terms of the Creative Commons Attribution License, which permits unrestricted use, distribution, and reproduction in any medium, provided the original author and source are credited. 
The concentration of the isolated AChE was determined by method described by Bradford [11].

\section{Determination of AChE concentration}

After crude AChE was extracted from the larvae of C. Partellus, the concentration was determined by the method described by Bradford [11] and bovine serum albumen (BSA) was the used as the standard for protein. The dye was made by dissolving $100 \mathrm{mg}$ coomassie Brilliant Blue G-250 in $50 \mathrm{ml} 95 \%$ ethanol followed by $100 \mathrm{ml} 85 \%$ (w/v) phosphoric acid. Absorbance was measured at $595 \mathrm{~nm}$ and the absorbance values were used to plot the standard curve. The standard curve was used to determine the concentration of the AChE.

\section{Anti-acetylcholinesterase activity assay}

Acetylcholinesterase activity was determined as described by Ellman method [12], with some modification that allowed the use of $1 \mathrm{ml}$ cuvette glass. In $2 \mathrm{ml}$ eppendorf tube, $150 \mu \mathrm{l}$ of $0.1 \mathrm{M}$ sodium phosphate buffer $(\mathrm{pH} 8)$ was put in which $10 \mu \mathrm{l}$ of the plant extract was added, followed by $20 \mu \mathrm{l}$ larvae homogenate (crude enzyme). Addition of $10 \mu \mathrm{l}$ of $14 \mathrm{mM}$ of acetythiocholine iodide was used as substrate to initiate the reaction. The eppendorf tube with the mixture was incubated for 30 minutes at $25^{\circ} \mathrm{C}$. The principle was to measure the production of thiocholine from the hydrolysis of acetylthiocholine iodide. Thereafter $10 \mu \mathrm{l}$ of $10 \mathrm{mM}$ of DTNB was added which was used for the measurement of $\mathrm{AChE}$ activity. The reaction mixture was then incubated for 5 minutes at room temperature $\left(25^{\circ} \mathrm{C}\right)$. The absorbance is read at $412 \mathrm{~nm}$ with spectrophotometer against a blank and reference pesticide used was cyclone. The optical density (OD) was read after one minute and the fourth minutes. Then the change optical density with time $(\mathrm{OD} / \mathrm{min})$ was calculated to estimate substrate hydrolysis overtime. One unit of AChE activity is defined as $1 \mu$ of substrate hydrolyzed per minute. The activity of the AChE was calculated using Beer lamberts law.

\section{Qualitative phytochemical screening}

Qualitative phytochemical screening was done to determine the presence of selected secondary metabolites. This was done according to the standard methods as described by Harborne [13] and Kotake [14].

\begin{tabular}{|c|c|c|c|}
\hline $\begin{array}{c}\text { Treatment } \\
(\mathbf{m g} / \mathbf{m l})\end{array}$ & $\begin{array}{c}\text { Mean change in } \\
\text { absorbance }\end{array}$ & $\begin{array}{c}\text { Enzyme activity } \\
\text { (pmoles/min/mg } \\
\text { protein) }\end{array}$ & $\begin{array}{c}\text { Mean \% } \\
\text { inhibition }\end{array}$ \\
\hline Normal control & $0.032 \pm 0.058$ & 0.000 & $0.00 \pm 0.00$ \\
\hline Positive control & $0.001 \pm 0.055$ & 3.744 & $96.97 \pm 1.84^{\mathrm{a}}$ \\
\hline $\mathbf{2 . 5}$ & $0.009 \pm 0.003$ & 4.444 & $73.64 \pm 8.67^{\mathrm{ab}}$ \\
\hline $\mathbf{5}$ & $0.013 \pm 0.028$ & 1.836 & $64.80 \pm 28.00^{\mathrm{ab}}$ \\
\hline $\mathbf{7 . 5}$ & $0.018 \pm 0.002$ & 0.902 & $45.45 \pm 6.19^{\mathrm{ab}}$ \\
\hline $\mathbf{2 5}$ & $0.021 \pm 0,004$ & 0.021 & $35.50 \pm 13.4^{\mathrm{b}}$ \\
\hline $\mathbf{5 0}$ & $0.028 \pm 0.036$ & 0.039 & $35.09 \pm 4.66^{\mathrm{b}}$ \\
\hline $\mathbf{7 5}$ & $0.037 \pm 0.033$ & 0.032 & $34.54 \pm 6.05^{\mathrm{b}}$ \\
\hline
\end{tabular}

Values are expressed as mean \pm SEM for triplicate readings. Values with different superscripts are significantly different calculated by one way ANOVA followed by Tukey's post hoc test ( $p>0.05)$.

Table 1: Effects of DCM leaf extracts of $C$. glaucescens on anti- acetylcholinesterase of $C$. partellus larvae.

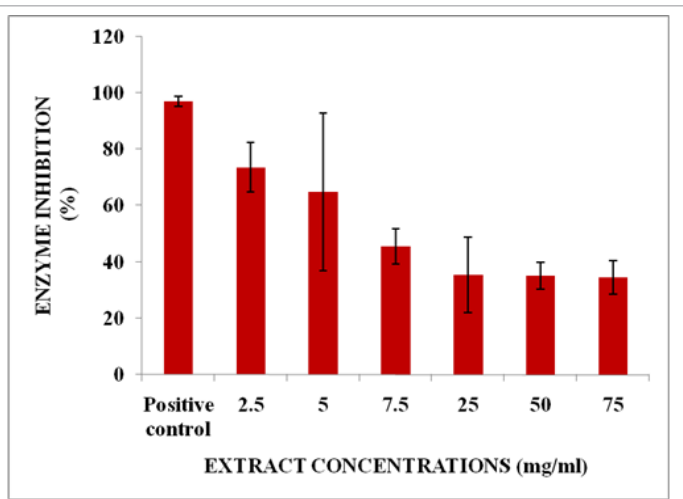

Figure 1: Comparison of percent inhibition at various concentrations of DCM leaf extracts of $C$. glaucescens on anti-acetylcholinesterase of $C$. partellus.

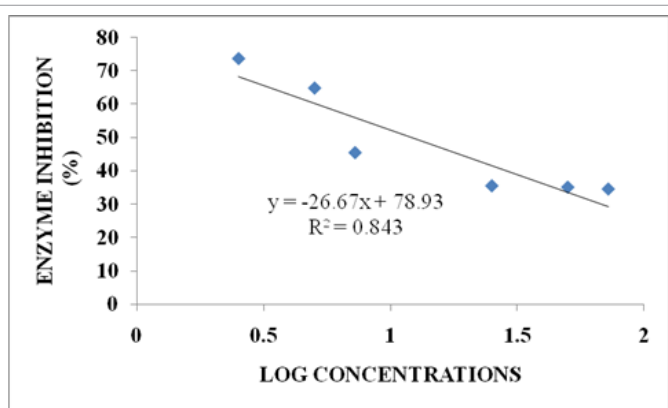

Figure 2: Linear regression graph with line of best fit for calculation $\mathrm{IC}_{50}$

\section{Data collection, management and statistical analysis}

Data collected included the efficacy of the extract against the AChE, change in absorbance, and qualitative phytochemical screening was also done. Data on phytochemical was presented on a table showing presence or absence of the phytochemicals. Data on different extract concentrations, and controls were analyzed using one way ANOVA, which was followed by Tukey's post hoc for pairwise separation and comparison of means. Minitab version 17 software was used for statistical analysis.

\section{Results and Discussion}

The DCM leaf extract of C. glaucescens showed efficacy against AChE activity in C. partellus as indicated by percent inhibition of the enzyme activity by various extract concentrations (Table 1 and Figure 1) using method described by [12]. Acetylcholinesterase plays a critical role in terminating synaptic transmission so that the next nerve impulse can be transmitted across the synapse. Therefore, the leaf extract has the potential to prevent the $\mathrm{AChE}$ of $C$. partellus in termination of nerve impulse. Among the six different extract concentrations, the $2.5 \mathrm{mg} / \mathrm{ml}$ had the highest percent inhibitory effects on activity of acetylcholinesterase with a value of $73.64 \%$ and $75 \mathrm{mg} / \mathrm{ml}$ had the lowest percentage enzyme activity inhibition of $34.54 \%$ (Table 1 and Figure 2). The normal control group had no effect against the enzyme activity. This is similar to a study conducted by Orhan [15], which demonstrated that all Fumaris species studied showed the most potent inhibitory activity against AChE. The high SEM for concentration $5 \mathrm{mg} / \mathrm{ml}$ (Figure 1) can be interpreted to mean that it was not a representative of the population however despite the high SEM the results were consistent with results of other concentrations.

From this study, any change in absorbance was also associated 
Citation: Anne NW, Piero NM, Umar A, Felix M, Maina GS, et al. (2016) In Vitro Anti-Acetylcholinesterase Activity of Dichloromethane Leaf Extracts of Carphalea glaucescens in Chilo partellus Larvae. Biochem Anal Biochem 5: 264. doi:10.4172/2161-1009.1000264

Page 3 of 3

with inhibition of enzyme activity. The $\mathrm{IC}_{50}$ for DCM leaf extract of $C$. glaucescens was computed by regression line and found to be $12.02 \mathrm{mg} /$ $\mathrm{ml}$ (Figure 2). At lower extract concentrations the extract was more sensitive to enzyme activity than at higher concentrations (Figure 3) which mean that to be effective only low concentrations of the extract would be required.

Results revealed that anti acetylcholinesterase activity of DCM leaf extracts of $C$. glaucescens in C. partellus is dose dependent because the extract concentration increased the percent enzyme inhibition decreased. This was comparable to a study by [16] which observed that Foliar application of semi-solid crude extract of T. orientalis on maize was found to be effective against $C$. partellus. In this study, the leaf extract showed enzyme inhibitory effects. The inactivated enzyme is no longer capable of hydrolyzing acetylcholine, resulting in the build up of ACh in the nerve synapse, leading to death $[17,18]$.

\section{Qualitative phytochemical screening}

In DCM extract of C. glaucescens phytochemicals which were present after screening were tannins, phenols, flavonoids, steroids, terpenoids and alkaloids. However saponins and cardiac glycosides were absent (Table 2). The bioactivity of DCM leaf extracts of $C$. glaucescens can be attributed to constituent phytochemicals such as phenols and flavonoids in the extracts which are associated with phenols and flavonoids [19]. Similarly, a study conducted by [15] found out that since most of the acetylcholinesterase inhibitors are known to contain nitrogen, the higher activity of these extracts may be due to their rich alkaloidal content.

\section{Conclusion}

In conclusion, this study has revealed that the DCM leaf extracts of $C$. glaucescens has the potential of in vitro anti acetylcholinesterase activity in C. partellus and it is possible for the studied plants to possess bioactive compounds. Therefore C. glaucescens can be used as biopesticide in the control of $C$. partellus. However the bioactivity could have been higher if pure extract were used and would recommend purification of AChE through processes such as chromatography.

\section{Acknowledgement}

Thanks are due to Mr. Daniel Gitonga for providing technical support.

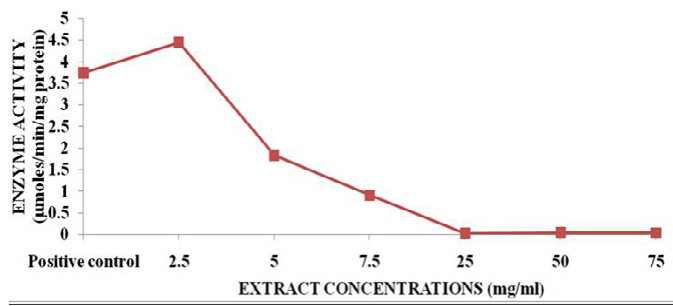

Figure 3: The dose dependent curve for in vitro AChE inhibition.

\begin{tabular}{|c|c|}
\hline Phytochemical & C. glaucescens \\
\hline Phenols & + \\
Flavonoids & + \\
Terpenoids & + \\
Saponins & + \\
Alkaloids & - \\
Cardiac glycosides Steroids & + \\
Tannins & + \\
\hline
\end{tabular}

(KEY: + = Present, - = Absent)

Table 2: Results of qualitative phytochemical screening of $C$. glaucescens.

\section{Refrences}

1. Melaku W, Fritz S, Kairu E, Omwega C (2006) Cereal yield losses caused by lepidopterous stem borers at different nitrogen fertilizer rates in Ethiopia. J App Entomol 130: 220-229.

2. Ofomata VC, Overholt WA, Egwuatu RI (1999) Diapause termination of Chilo partellus (Swinhoe) and Chilo orichalcociliellus Strand (Lepidoptera: Pyralidae). Insect Sci Appl 19: 187-191.

3. Ofomata VC, Overholt WA, Van Huis A, Egwuatu RI, Ngi-Song AJ (1999b) Niche overlap and interspecific association between of Chilo partellus and Chilo orichalcociliellus on the Kenya coast. Entomol Exp Appl 93: 141-148.

4. Ofomata VC, Overholt W, Lux SA, Van Huis A, Egwuatu RI (2000) Comparative studies on the fecundity, egg survival, larval feeding and development of Chilo partellus (Swinhoe)and Chilo orichalcociliellus Strand (Lepidoptera: Crambidae) on five grasses. Ann Entomol Soc Am 93: 492-499.

5. Harris KM (1989) Bioecology and Chilo species. Insect Sci Appl 11: 467-477.

6. Ingram WR (1983) Biological controls of graminacerous stem borers and legume pod borers. Insect Sci Appl 4: 205-209.

7. Christos AD, llias GE (2011) pesticide exposure, safety issues, and rise assessment indicators, Int J Environ Res Publ Health 8: 1402-1419.

8. Yu SJ (2008) The toxicology and biochemistry of insecticides, CRC Press Boca Raton, Florida, USA.

9. Dua R, Gill KD (2001) Aluminium phosphide exposure: implications on rat brain lipid peroxidation and antioxidant defence system. Pharmacol Toxicol 89: 315319.

10. World Health Organization (2002) World Health Organization Traditional medicine strategy 2002-2005, Geneva.

11. Bradford MM (1976) Rapid and sensitive method for quantitation of microgram quantities of protein utilizing principle of protein dye binding. Anal Biochem 72 : 248-254.

12. Ellman GL, Courtney KD, Andres V, Featherstone RM (1961) A new and rapid colorimetric determination of acetylcholinesterase activity. Biochem Pharmacol 7: 88-95.

13. Harborne AJ (1998) Phytochemical Methods: A guide to modern techniques of plant analysis. London Chapman.

14. Kotake C (2000) Practical Pharmacognosy. Vallabh Prakashan, New Delhi, India 4: 107-111.

15. Orhan I, Sener B, Choudhary MI, Khalid A (2004) Acetylcholinesterase and butyrycholinesterase inhibitory activity of some Turkish medicinal plants. J Ethnopharmacol 91: 57-60.

16. Anju B, Sharma V (1999) Relative toxicity and persistence of plant products against maize stem borer on maize. Ann Plant Prot Sci 7: 144-149.

17. O'Brien R (1967) Insecticides action and metabolism, Academic Press, New York. Orgaization of the United Nations.

18. Pang YP (2006) Novel acetylcholinesterase target site for malaria mosquito control. PLoS 1: 58-64.

19. Wang CY, Ng CC, Lin HT, Shyu YT (2011) Free radical-scavenging and tyrosinae-inhibiting activities of extracts from sorghum distillery residue. J Bioengin 111: 554-556. 